\section{Response to: 'Medications associated with fracture risk in patients with rheumatoid arthritis' by Chen et al}

We appreciate the interest shown by Dr Chen ${ }^{1}$ concerning our recent study on medications associated with fracture risk in patients with rheumatoid arthritis (RA). ${ }^{2}$ We would like to clarify some issues Chen et al indicated.

First, we agree that osteoporotic fractures are more common in patients with inflammatory diseases. However, in our study, we excluded all patients with prevalent fractures to estimate the risk related to new fractures. Our study only shows the osteoporosis site fracture incidence in patients with RA. As we indicated in our manuscript, the incidence rate of osteoporotic fractures in our cohort is similar to a recent meta-analysis of 25 cohort studies in patients with RA. ${ }^{3}$

Second, it is possible that high-intensity statin regimens may prevent fractures better than moderate-intensity ones especially if the protective effects are assumed to be due to anti-inflammatory properties of statins. Moreover, as Chen et al indicate, some antihypertensives may have protective effects on osteoporotic fracture risk. However, the only randomised controlled trial for this association is with thiazide diuretics ${ }^{45}$ of which effect is also more biologically plausible compared with other antihypertensives. ${ }^{6}$ The fracture risk change with high-intensity statins and antihypertensives should be investigated further in patients with RA.

Lastly, we appreciate the comment about our outcome-only osteoporosis site fractures. It is well-known that patients with RA have increased fall risk, which can also cause fractures. Unfortunately, we do not have any data for the level of trauma and fall risk other than disability scores. Regardless, we believe that including all types of fractures would make our outcome very heterogeneous. A significant trauma could cause a fracture in any patient even in the absence of risk factors. We are planning to collect more data regarding fall risk to better assess the fracture risk in our cohort.

Gulsen Ozen $\odot{ }^{1}$ Kaleb Michaud ${ }^{1,2}$

${ }^{1}$ Internal Medicine, University of Nebraska Medical Center, Omaha, Nebraska, USA
${ }^{2}$ FORWARD, The National Databank for Rheumatic Diseases, Wichita, Kansas, USA

Correspondence to Dr Kaleb Michaud, National Data Bank for Rheumatic Diseases, Wichita, KS 67214, USA; kmichaud@unmc.edu

Handling editor Josef S Smolen

Twitter Gulsen Ozen @Dr_K and Kaleb Michaud @Dr_K

Competing interests None declared.

Patient consent for publication Not required.

Provenance and peer review Commissioned; internally peer reviewed.

(C) Author(s) (or their employer(s)) 2019. No commercial re-use. See rights and permissions. Published by BMJ.

\section{Check for updates}

To cite Ozen G, Michaud K. Ann Rheum Dis Epub ahead of print: [please include Day Month Year]. doi:10.1136/annrheumdis-2019-216293

Received 1 October 2019

Accepted 1 October 2019

\section{SLinked}

http://dx.doi.org/10.1136/annrheumdis-2019-216262

Ann Rheum Dis 2019;0:1. doi:10.1136/annrheumdis-2019-216293

ORCID iDs

Gulsen Ozen http://orcid.org/0000-0002-5423-393X

Kaleb Michaud http://orcid.org/0000-0002-5350-3934

\section{REFERENCES}

1 Chen HY, Lin TK, Liou YS, et al. Medications associated with fracture risk in patients with rheumatoid arthritis. Ann Rheum Dis 2019. [Epub ahead of print: 17 Sep 2019].

2 Ozen G, Pedro S, Wolfe F, et al. Medications associated with fracture risk in patients with rheumatoid arthritis. Ann Rheum Dis 2019;78:1041-7.

3 Jin S, Hsieh E, Peng L, et al. Incidence of fractures among patients with rheumatoid arthritis: a systematic review and meta-analysis. Osteoporos Int 2018;29:1263-75.

4 Puttnam R, Davis BR, Pressel SL, et al. Association of 3 different antihypertensive medications with hip and pelvic fracture risk in older adults: secondary analysis of a randomized clinical trial. JAMA Intern Med 2017;177:67-76.

5 Peters R, Beckett N, Burch L, et al. The effect of treatment based on a diuretic (indapamide) +/-ACE inhibitor (perindopril) on fractures in the hypertension in the very elderly trial (HYVET). Age Ageing 2010;39:609-16.

6 LaCroix AZ, Ott SM, Ichikawa L, et al. Low-Dose hydrochlorothiazide and preservation of bone mineral density in older adults. A randomized, double-blind, placebo-controlled trial. Ann Intern Med 2000;133:516-26. 